\title{
Resurrection of a regionally extinct taxon in Croatia - the case of Ammophila arenaria (L.) Link (Poaceae)
}

\author{
Sandro Bogdanovicí ${ }^{1,2^{*}}$, Vedran Šegota ${ }^{3}$, Antun Alegro $^{3}$ \\ ${ }^{1}$ University of Zagreb, Faculty of Agriculture, Department of Agricultural Botany, Svetošimunska 25, 10000 Zagreb \\ ${ }^{2}$ Centre of Excellence for Biodiversity and Molecular Plant Breeding, Svetošimunska 25, 10000 Zagreb \\ ${ }^{3}$ University of Zagreb, Faculty of Science, Department of Biology, Division of Botany, Herbarium Croaticum, Marulićev \\ $\operatorname{trg}$ 20/2, 10000 Zagreb, Croatia
}

\begin{abstract}
A regionally extinct taxon, Ammophila arenaria (L.) Link subsp. arundinacea H. Lindb., has been rediscovered in the Croatian flora after 78 years. Previously it was known only from two coastal sand dune sites in Northern Dalmatia. The habitat at the locality of Crnika near Lopar on the northern Adriatic island of Rab is destroyed and A. arenaria subsp. arundinacea does not grow there anymore. At the second locality, on the sand dunes of Kraljičina plaža in the vicinity of the town of Nin, A. arenaria subsp. arundinacea was rediscovered and confirmed after 174 years. This is the only population of this taxon in Croatia, counting 48 mature individuals where the psammophylous habitat of Kraljičina plaža is under strong anthropogenic influence. This taxon is now classified as critically endangered (CR) and merits adequate active protection and conservation of its psammophylous habitat.
\end{abstract}

Key words: Ammophila, conservation, extinction, Nin, psammophytes, rare species

\section{Introduction}

The species European beachgrass, Ammophila arenaria (L.) Link, belongs to the family Poaceae and it is a typical psammophylous grass that inhabits coastal sand dunes from the eastern Atlantic coasts of Europe to the Mediterranean area (Tutin 1980, Valdés and Scholz 2009). The species is represented by two subspecies along the distribution area: the typical A. arenaria (L.) Link subsp. arenaria is distributed along the Atlantic sandy coasts of North and West Europe, southwards to the French Basque Country, while the second one, A. arenaria subsp. arundinacea $\mathrm{H}$. Lindb is distributed on the coasts of South Europe, from Romania to Portugal, with the northern limit in the French Basque County (Tutin 1980, Biurrun et al. 2012, Marcenò and Jiménez-Alfaro 2017).

In the Croatian flora the taxon A. arenaria subsp. arundinacea was mentioned for the first time by Alschinger (1832: 27) as Psamma arenaria Beauv. for the area of Aenona (the town of Nin) in the vicinity of the town of Zadar in Northern Dalmatia. Subsequently, Visiani (1842: 79) cited the same locality "circa Nona" in his Flora Dalmatica, as did Schlosser and Vukotinović (1869: 1232) in Flora Croatica. Afterwards, it was recorded by Morton (1915:249) as Ammophila pallida
(C. Presl) Fritsch var. australis Mabille and by Horvatić (1939: 25), both for the same locality (Crnika near the village of Lopar) on the island of Rab. To conclude, these were the only two known localities of A. arenaria subsp. arundinacea in the Croatian flora for more than eight last decades.

During the re-evaluation of the national Red list of vascular flora of Croatia, Ilijanić (2005) evaluated the taxon A. arenaria subsp. arundinacea as a regionally extinct (RE) with a note "Extinct in the wild, with a very small possibility of re-finding due to habitat loss". The author underlined various intensive touristic activities on sandy beaches as a main reason for the extinction of this taxon.

\section{Materials and methods}

Field investigation was carried out on Kraljičina plaža $\left(44^{\circ} 15^{\prime} 0.89^{\prime \prime} \mathrm{N}, 15^{\circ} 10^{\prime} 37.28^{\prime \prime} \mathrm{E}\right)$ in the vicinity of the town of Nin in Northern Dalmatia, and in Crnika near the village of Lopar ( $\left.44^{\circ} 49^{\prime} 25^{\prime \prime} \mathrm{N}, 14^{\circ} 44^{\prime} 26^{\prime \prime} \mathrm{E}\right)$ on the island of Rab during the vegetation season of May, June and July of 2016 (Fig. 1). Additionally, the flora of the entire South-Eastern coast

\footnotetext{
* Corresponding author, e-mail: sbogdanovic@agr.hr
} 


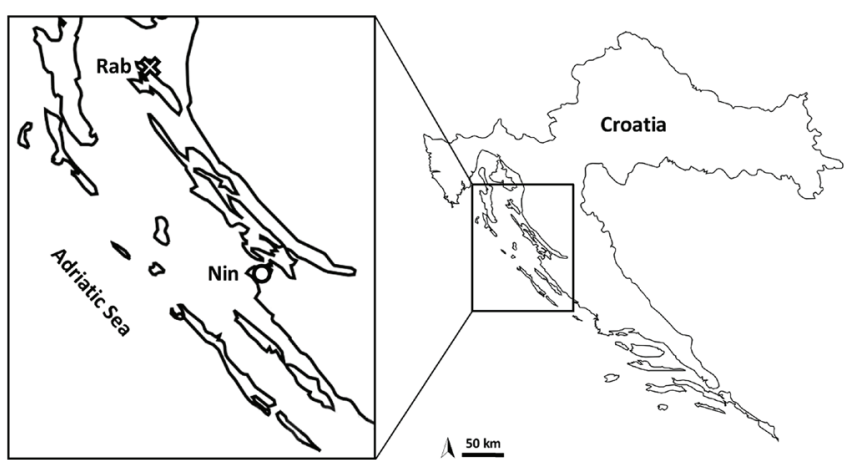

Fig. 1. Map of the investigated area in the vicinity of the town of Nin (Kraljičina plaža) and the island of Rab (Lopar). Symbols indicate presence at $(\mathrm{O})$ and absence from a previous known locality $(\mathrm{x})$ of Ammophila arenaria (L.) Link subsp. arundinacea H. Lindb.

around Lopar, consisting of dozens of sandy beaches was carefully checked. Plant material of psammophylous flora was collected and deposited in herbaria ZA and ZAGR. Abbreviations are according to Thiers (2016). For the purpose of documentation and for available public access to herbaria, specimens of A. arenaria subsp. arundinacea were geo-coded, digitalized and inserted in Flora Croatica Database (Nikolić 2016) and in the publicly accessible Virtual Herbarium ZAGR (Bogdanović et al. 2016).

Vegetation relevés were made using the expanded Braun Banquet scale (Braun-Blanquet 1964, Barkman et al. 1964, Dierschke 1994). Category 2 was subdivided into $2 \mathrm{~m}, 2 \mathrm{a}$ and $2 \mathrm{~b}$. In total, three phytosociological relevés with plot sizes of $5 \times 5 \mathrm{~m}$ were made in June of 2016 . The species nomenclature follows the Flora Croatica Database (Nikolić 2016) and Euro+Med (2017).

For the assessment of population status and conservation issues of $A$. arenaria subsp. arundinacea the IUCN criteria and categories were adopted according to guidelines of IUCN (2014).

\section{Results and discussion}

Our finding of A. arenaria subsp. arundinacea on the sand dunes around the town of Nin in Northern Dalmatia raised the question of its extinction and its conservation status in Croatia. The resurrection of a regionally extinct plant taxon in Croatian flora after the last Red List evaluations is uncommon. In eleven years, only Botrychium matricariifolium W.D.J.Koch has been rediscovered (but at a different locality), thirty years after its disappearance (Borovečki-Voska et al. 2011). More recently Franjić et al. (2016) confirmed the existence of Hippophae rhamnoides L. in the Croatian flora, and both species were consequently removed from the list of extinct taxa. The case of $A$. arenaria subsp. arundinacea is the third one, and here we provide detailed information about the morphology, distribution, habitat, phytosociology and conservation status of this taxon, which is one of the rarest plant species in the Croatian flora:
Morphology - A. arenaria subsp. arundinacea is a perennial rhizomatous grass with erect stems up to $170 \mathrm{~cm}$. Leaves are convolute, rigid, strongly ribbed, ca $5 \mathrm{~mm}$ wide, with bifid, up to $30 \mathrm{~mm}$ long ligule. Inflorescence is erect, a dense cylindrical panicle up to $30 \mathrm{~cm}$ long (Fig. 2). Spikelets are 12-14 mm long, with 1 floret. Glumes are linear-lanceolate, about equal to the lemma. Lemma has 4-5 $\mathrm{mm}$ long hairs at the base, while in A. arenaria subsp. arenaria the glumes distinctly exceed the lemma, and the lemma has hairs ca $2 \mathrm{~mm}$ long at the base. Ovary is glabrous (Tutin 1980).

Distribution in Croatia - The only site of this taxon is in Northern Dalmatia on the sand dunes of Kraljičina plaža in the vicinity of the town of Nin. The habitat of the historical record on Crnika in Lopar from the island of Rab is devastated and destroyed by touristic development (Fig. 1), as foreseen by Ilijanić (1987). A field survey of all the sandy beaches on North-Eastern part of the island of Rab revealed no new findings.

Specimina visa - Croatia: Otok Rab, pješčane sipine uz dragu Crniku u Loparskoj dolini, asoc. Agropyretum mediterraneum, 31.05.1935, S. Horvatić s.n. (ZA 7197); Dalmacija, Nin, Ninsko blato, Kraljičina plaža, obalna pješčana dina, $44^{\circ} 15^{\prime} 0,89^{\prime \prime} \mathrm{N}, 15^{\circ} 10^{\prime} 37,28^{\prime \prime}$ E, 07.05.2016, S. Bogdanović \& V. Šegota s.n. (ZAGR 41250).

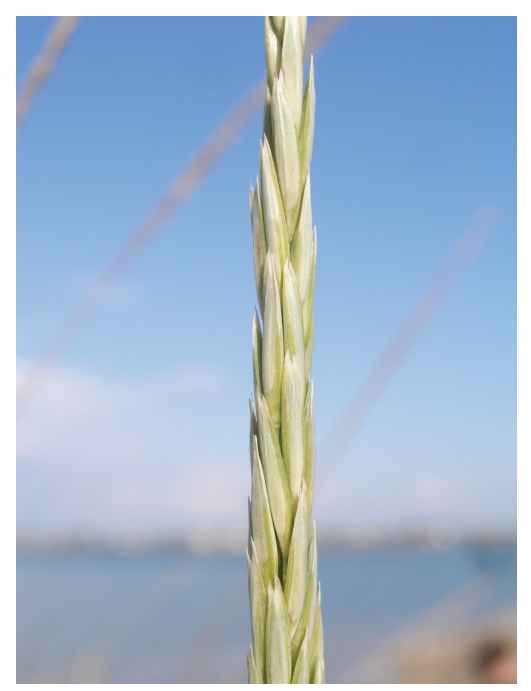

Fig. 2. Inflorescence of Ammophila arenaria (L.) Link subsp. arundinacea $\mathrm{H}$. Lindb. (photo by S. Bogdanović).

Habitat and phytosociology - A. arenaria subsp. arundinacea is a characteristic species of the order Ammophiletalia Br.-Bl. et Tx. ex Westhoff et al. 1946, growing on primary embryonic mobile sand dunes (Biondi and Galdenzi 2014). The species was found to be in a good state, with average height and at the time of our visit majority of the plants were in bloom. At the locality Kraljičina plaža it grows in typical psammophytic vegetation (Fig. 3) with some other very rare psammophylous taxa of the Croatian flora: Cyperus capitatus Vand., Phleum arenarium L., Stachys maritima Gouan, Elytrigia juncea (L.) Nevski subsp. juncea, Armeria canescens (Host) Boiss. in DC. subsp. dalmatica (Beck) Trinajstić and Calystegia soldanella (L). R. Br. Sandy coastal habitats in 


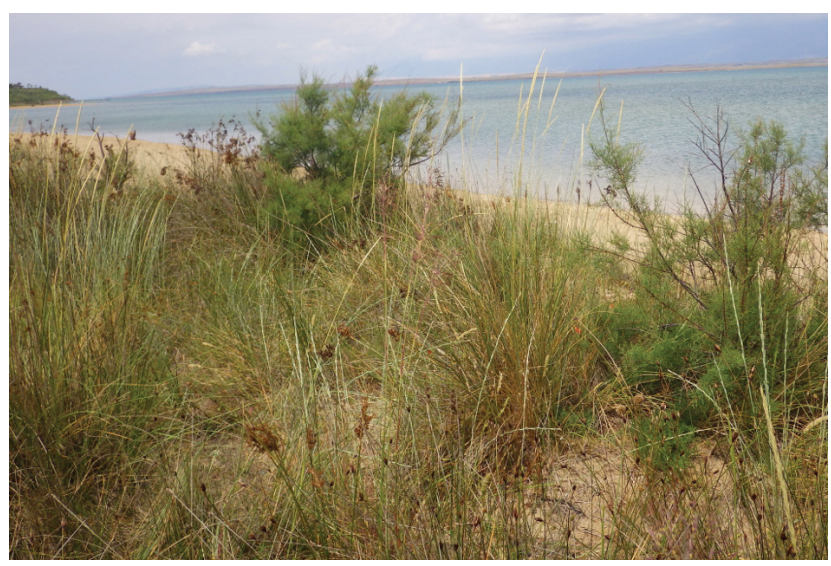

Fig. 3. Habitat of Ammophila arenaria (L.) Link subsp. arundinacea H. Lindb. in Kraljičina plaža near the town of Nin (photo by V. Šegota).

Croatia are very rare and psammophytic vegetation of the order Ammophiletalia is extremely endangered (Alegro et al. 2004). Due to the very small and localized areas of these habitats, as well as by the quoted psammophytic species they are also colonized by many species of neighbouring ruderalized habitats as can be seen from those three phytosociological relevés (Tab. 1). Therefore, the researched community can be considered an impoverished wet variant of the association Euphorbio paraliae-Agropyretum junceiformis Tüxen in Br.-Bl. et Tüxen 1952 corr. Darimont, Duvigneaud et Lambinon 1962 (Ammophilion Br.-Bl. 1921, Ammophiletalia Br.-Bl. et Tüxen ex Westhoff et al. 1946) as defined by Šilc et al. (2016).

Conservation status - In June 2016, we observed and counted 48 mature individuals along the sand dune at only one location. According to IUCN (2014) for the evaluation of $A$. arenaria subsp. arundinacea the criterion D (very small or restricted population) could be applied. The area of occupancy (AOO) and the extent of occurrence (EOO) are both less than $10 \mathrm{~km}^{2}$. The number of locations is one, continued decline is observed in $\mathrm{EOO}$ and $\mathrm{AOO}$, in habitat quality and number of locations. Adopting the IUCN (2014) criteria $A$. arenaria subsp. arundinacea should be classified as critically endangered (CR) based on following criteria: $\mathrm{B} 1 \mathrm{a}(\mathrm{i}, \mathrm{ii}, \mathrm{iii}, \mathrm{iv})+\mathrm{B} 2 \mathrm{~b}(\mathrm{i}, \mathrm{ii}, \mathrm{iii}, \mathrm{iv})$ and $\mathrm{D}$. The sand dunes of Kraljičina plaža are under strong anthropogenic influence, and the major threat to this taxon and to other critically endangered plant taxa of this area (Cyperus capitatus and Calystegia soldanella) is the human impact due to various touristic activities, e.g. removing the plant cover and exploitation and transportation of the sand for enlargement of sandy beaches, construction of infrastructure for local beach bars, etc.

\section{Conclusions}

According to the Flora Croatica Database (Nikolić 2016), the Croatian flora has eight regionally extinct taxa: Caldesia parnassifolia (L.) Parl., Cuscuta epilinum Weihe,
Tab. 1. Phytosociological relevés collected from Kraljičina plaža near the town of Nin. Coordinates of relevés: Rel. 1: $44^{\circ} 15^{\prime} 14^{\prime \prime} \mathrm{N}$,

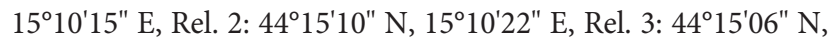
$15^{\circ} 10^{\prime} 30^{\prime \prime} \mathrm{E}$.

\begin{tabular}{|c|c|c|c|}
\hline Relevés no. & 1 & 2 & 3 \\
\hline Surface $\left(\mathrm{m}^{2}\right)$ & 25 & 25 & 25 \\
\hline Vascular plant cover (\%) & 80 & 80 & 80 \\
\hline $\begin{array}{l}\text { Ammophila arenaria (L.) Link subsp. } \\
\text { arundinacea } \mathrm{H} \text {. Lindb }\end{array}$ & 1 & $2 b$ & $2 b$ \\
\hline Elytrigia juncea (L.) Nevski subsp. juncea & 1 & $2 \mathrm{a}$ & 1 \\
\hline $\begin{array}{l}\text { Armeria canescens (Host) Boiss. in DC. subsp. } \\
\text { dalmatica (G. Beck) Trinajstić }\end{array}$ & . & $2 \mathrm{~m}$ & $2 \mathrm{~m}$ \\
\hline Euphorbia paralias L. & 1 & . & . \\
\hline Vulpia ciliata Dumort. & . & 1 & + \\
\hline Phleum arenarium $\mathrm{L}$. & . & . & 1 \\
\hline Stachys maritima Gouan & + & . & . \\
\hline Cyperus capitatus Vand. & $2 \mathrm{a}$ & . & . \\
\hline Schoenus nigricans L. & . & $2 \mathrm{a}$ & . \\
\hline Juncus acutus L. & . & 1 & $2 \mathrm{a}$ \\
\hline Limonium virgatum (Willd.) Fourr. & . & $2 \mathrm{~m}$ & $2 \mathrm{~m}$ \\
\hline Cynodon dactylon (L.) Pers. & 1 & 1 & $2 \mathrm{a}$ \\
\hline Papaver rhoeas L. & + & $2 \mathrm{~m}$ & 1 \\
\hline Silene vulgaris (Moench) Garcke & + & 1 & + \\
\hline Anthericum liliago L. & + & . & . \\
\hline Scolymus hispanicus L. & + & + & . \\
\hline Clematis flammula $\mathrm{L}$. & + & + & $\mathrm{r}$ \\
\hline Allium sphaerocephalon $\mathrm{L}$. & . & + & + \\
\hline Dactylis glomerata $\mathrm{L}$. & . & + & . \\
\hline Scirpus holoschoenus L. & . & 1 & 1 \\
\hline Melica ciliata $\mathrm{L}$. & . & 1 & + \\
\hline Rubus ulmifolius Schott & . & + & . \\
\hline Chrysopogon gryllus (L.) Trin. & . & + & . \\
\hline Elymus pycnanthus (Godr.) Melderis & . & + & . \\
\hline Tamarix sp. (planted) & . & + & + \\
\hline Elymus repens (L.) Gould & . & . & 1 \\
\hline Anagallis arvensis $\mathrm{L}$. & . & . & + \\
\hline Arenaria leptoclados (Rchb.) Guss. & . & . & + \\
\hline Cakile maritima Scop. & . & . & 1 \\
\hline Catapodium rigidum (L.) C. E. Hubb. & . & . & + \\
\hline Herniaria glabra L. & . & . & + \\
\hline Lagurus ovatus L. & . & . & $2 \mathrm{~m}$ \\
\hline Petrorhagia saxifraga (L.) Link & . & . & + \\
\hline Reichardia picroides (L.) Roth & . & . & + \\
\hline Sedum acre L. & . & . & + \\
\hline $\begin{array}{l}\text { Seseli montanum L. subsp. tommasinii (Rchb. } \\
\text { f.) Arcang. }\end{array}$ & & . & + \\
\hline Trifolium scabrum L. & & . & + \\
\hline Valantia muralis $\mathrm{L}$. & & . & + \\
\hline Helichrysum italicum (Roth) G. Don & & . & $2 a$ \\
\hline
\end{tabular}

Cyperus glaber L., Drosera anglica Huds., D. intermedia Hayne, Eriophorum gracile Roth, Eryngium planum L. and Ammophila arenaria (L.) Link subsp. arundinacea $\mathrm{H}$. Lindb. Due to our finding, the last one has to be removed now from that list and treated as critically endangered; however urgent protection actions are needed for conservation of this taxon rediscovered in the wild. 


\section{Acknowledgements}

The authors would like to thank the president of the Croatian Botanical Society (HBoD) for logistic and fi- nancial support during this research and to our colleagues Nikola Koletić for providing the distribution map and Igor Boršić $\mathrm{PhD}$ for valuable comments on conservation issues.

\section{References}

Alegro, A., Biljaković, M., Bogdanović, S., Boršić, I., 2004: Psammo-halophytic vegetation on the largest sand area on the Croatian coast: the island of Mljet, southern Adriatic. Biologia, Bratislava 59, 435-445.

Alschinger, A., 1832: Flora Jadrensis. Typ. Battara, Zadar (Jaderae).

Barkman, J. J., Doing, H., Segal. S., 1964: Kritische Bemerkungen und Vorschläge zur quantitativen Vegetationsanalyse. Acta Botanica Neerlandica 13, 394-419.

Biondi, E., Galdenzi, D., 2014: Syntaxonomic considerations of the Mediterranean vegetation dominated by perennial psammophilous graminaceous plants. Plant Sociology 51, 25-32.

Biurrun, I., García-Mijangos, I., Campos, J.A., Herrera, M., Loidi, J., 2012: Vegetation-plot database of the University of the Basque Country (BIOVEG). Biodiversity and Ecology 4, 328.

Bogdanović, S., Britvec, M., Dujmović Purgar, D., Ljubičić, I., Vitasović Kosić, I., 2016: Herbarium ZAGR of the Faculty of Agriculture (Zagreb, Croatia). Agriculturae Conspectus Scientificus 81, 1-5.

Borovečki-Voska, Lj., Čičmir, R., Šincek, D., 2011: New finding of the species Botrychium matricarifolium (Retz.) A. Br. ex Koch (Ophioglossaceae) in Croatia. Natura Croatica 20, 229-233.

Braun-Blanquet, J., 1964: Pflanzensoziologie. Grundzüge der Vegetationskunde. 3. Aufl. Springer Verl., Wien, New York.

Dierschke, H., 1994: Pflanzensoziologie. Grundlagen und Methoden. Eugen Ulmer Verl., Stuttgart.

Euro+Med, 2017: Euro+Med PlantBase - the information resource for Euro-Mediterranean plant diversity. Retrieved May 16, 2017 from http://ww2.bgbm.org/EuroPlusMed/.

Franjić, J., Horvat, G., Krstonošić, D., 2016: New localities and syntaxonomic characteristics of sea buckthorn (Hippophaë rhamnoides L., Elaeagnaceae) in Croatia. Šumarski list 3-4, 111-116.

Horvatić, S., 1939: Overview of the vegetation of the island of $\mathrm{Rab}$ in terms of phytosociology. Prirodoslovna istraživanja Kraljevine Jugoslavije 22, 1-96 (in Croatian).

Ilijanić, Lj., 1987: Vegetational and biogeographic characteristics of the island of Rab. In: Mohorovičić, A. (ed.), Rapski zbornik, 83-97. JAZU and Skupština Općine Rab (in Croatian).
Ilijanić, Lj., 2005: Ammophila arenaria (L.) Link ssp. arundinacea H. Lindb. In: Nikolić, T., Topić, J. (eds.), Red Book of vascular flora of Croatia, 82-83. Ministarstvo kulture, Državni zavod za zaštitu prirode, Zagreb (in Croatian).

IUCN, 2014: IUCN standards and petitions subcommittee. Guidelines for using the IUCN red list categories and criteria. Version 11.1. Prepared by the standards and petitions subcommittee. Retrieved December 21, 2016 from http://www. iuc-nredlist.org/documents/RedListGuidelines.pdf

Marcenò, C., Jiménez-Alfaro, B., 2017: The Mediterranean Ammophiletea Database: a comprehensive dataset of coastal dune vegetation. Phytocoenologia 47, 95-105.

Morton, F., 1915: Pflanzengeographische Monographie der Inselgruppe Arbe, umfassend die Inseln Arbe, Dolin, S. Gregorio, Goli und Pervicchio sammt den umliegenden Scoglien. Botanische Jahrbücher für Systematik, Pflanzengeschichte und Pflanzengeographie 116, 67-273.

Nikolić, T., (ed.) 2016: Flora Croatica Database. University of Zagreb, Faculty of Science, Department of Botany. Retrieved December 27, 2016 from http://hirc.botanic.hr/fcd/.

Schlosser, J. C., Vukotinović, Lj. F., 1869: Flora Croatica: exhibens stirpes phanerogamas et vasculares cryptogamas quae in Croatia, Slavonia et Dalmatia sponte crescunt nec non illas quae frequentissime coluntur. Zagrabiae.

Šilc, U., Mullaj, A., Alegro, A., Ibraliu, A., Dajić Stevanović, Z., Luković, M., Stešević, D., 2016: Sand dune vegetation along the eastern Adriatic coast. Phytocoenologia 46, 339-355.

Thiers, B., 2016: Index Herbariorum: A global directory of public herbaria and associated staff. New York Botanical Garden's Virtual Herbarium. Retrieved December 27, 2016 from: http://sweetgum.nybg.org/ih/.

Tutin, T. G. 1980: Ammophila (L.) Link. In: Tutin, T. G., Heywood, V. H., Burges, N. A., Moore, D. M., Valentine, D. H., Walters, S. M., Webb, D. A. (eds.), Flora Europaea vol. 5, 236, Cambridge University Press, Cambridge.

Valdés, B., Scholz, H., 2009: Poaceae (pro parte majore). Euro+Med Plantbase - the information resource for EuroMediterranean plant diversity. Retrieved December 27, 2016 from: http://ww2.bgbm.org/EuroPlusMed/query.asp

Visiani, R., 1842: Flora Dalmatica 1. Apud Fridericum Hofmeister, Lipsiae. 